\title{
Increasing Self-esteem through Traditional Sundanese Games and Sport from Indonesia in Physical Education
}

\author{
Indra Adi Budiman, Brio Alfatihah Rama Yudha*, Yoyo Zakaria Anshori \\ Faculty of Teacher Training and Education, Universitas Majalengka, Jawa Barat, Indonesia
}

Received April 24, 2021; Revised June 15, 2021; Accepted July 17, 2021

\section{Cite This Paper in the following Citation Styles}

(a): [1] Indra Adi Budiman, Brio Alfatihah Rama Yudha, Yoyo Zakaria Anshori, "Increasing Self-esteem through Traditional Sundanese Games and Sport from Indonesia in Physical Education," International Journal of Human Movement and Sports Sciences, Vol. 9, No. 4A, pp. 25 - 30, 2021. DOI: 10.13189/saj.2021.091305.

(b): Indra Adi Budiman, Brio Alfatihah Rama Yudha, Yoyo Zakaria Anshori (2021). Increasing Self-esteem through Traditional Sundanese Games and Sport from Indonesia in Physical Education. International Journal of Human Movement and Sports Sciences, 9(4A), 25 - 30. DOI: 10.13189/saj.2021.091305.

Copyright $\odot 2021$ by authors, all rights reserved. Authors agree that this article remains permanently open access under the terms of the Creative Commons Attribution License 4.0 International License

\begin{abstract}
Self-esteem has been identified as an initial buffer against childhood mental illness and with participation in physical activity as an approach to mental health promotion, as well as additional therapy treatments for mental illness. The purpose of this study was to determine the results of the traditional Sundanese ethnic game intervention on the self-esteem of elementary school students in physical education learning. The method used in this research is quasi-experimental. Participants in this study were all students of grade 6 elementary school and were selected as the experimental group $(\mathrm{N}=30)$ and one class 6 as the control group $(\mathrm{N}=30)$. The experimental group and the control group were treated for 12 weeks. The instrument used in this study was the Self-esteem Rating Scale (SERS). Paired t-test results obtained $\mathrm{p}<0.05$ and $t$ count $>t$ table or $2.830>2.143$, so it can be said that there is a significant difference in the experimental group's self-esteem before and after the application of traditional Sundanese ethnic game treatment in physical education learning. Based on the results of the research and discussion that have been described and explained above, it can be concluded that through traditional Sundanese ethnic games, the self-esteem of elementary school students can be increased.
\end{abstract}

Keywords Self-esteem, Physical Education, Traditional Sport, Traditional Games

\section{Introduction}

The Experts define Self-esteem with a variety of understandings, including, a person's evaluative judgment about himself [1], feelings about one's Self-Esteem [2], and how well a person appreciates, approves, or likes himself (not there is no doubt that positive self-esteem is the desired outcome of an academic, sports, and psychotherapy setting [3].

Social life and competence that is owned so that it is perceived as a factor that affects the development of self-esteem at childhood and adolescence. From these factors, an external perception will emerge in the form of responses and assessments from parents, friends, teachers [4]. From the research that has been done that if a person wants to improve the quality of life and health, he must have good self-esteem, because good self-esteem is the initial capital that can build positive psychology in his life [5]. Another study found that students who have good and positive self-esteem will be a crucial factor in motivation and success in academics so that they are happier and more confident in living their lives $[6,8]$. This is because Self-Esteem has a relationship with achievement at school.

Self-esteem has been identified as an early buffer of mental illness in childhood [9] and with participation in physical activity as a mental health promotion approach, as well as additional therapy treatments for mental illness [10]. While the health benefits of physical activity are well documented [11,12], the mental health benefits of physical 
activity for children and adolescents are less studied. Three important outcomes of particular relevance for the mental health of children and adolescents are depression, anxiety, and self-esteem.

In preventing and reducing the risk of mental illness in childhood, self-esteem is an important factor and has a role for it [9] and other factors in addressing the risk of mental illness and improving mental health can be through participation in sports and physical activity [10]. Other benefits of physical activity have been suggested in several previous studies [11,12], however, there is still a lack of research into physical activity that links directly to mental health. Even though the relationship between physical activity and mental health is linked by three factors: anxiety, depression and self-esteem. Low anxiety is related to the increased ability to use skills in life [13] while self-esteem is a dominant factor as a link between physical activity and mental health in children and adolescents [14]. Physical activity shows potential benefits for reducing depression and small benefits for reducing anxiety and self-esteem [14].

Individuals with high self-esteem are associated with mental health [15] and identified as protective factors against mental illness and suicidal behavior [16,17]. On the contrary, if the individual has low self-esteem, negative behavior will arise in his life such as drug abuse, deterioration of academic achievement and delinquent behavior [18,19], anxiety, depression, emotional difficulties [20], eating disorders [21], and even suicidal ideation [22]. Furthermore, regarding the study of self-esteem, that self-esteem is also a determining factor for an individual in achieving life satisfaction [23,24]. However, the close relationship between self-esteem and life satisfaction can be influenced by living habits in a country or culture that is used in a particular environment [25].

We include traditional Sundanese games and sports from Indonesia in Physical Education lessons to increase self-esteem and as an intermediary factor for the student life satisfaction. This is based on the inconsistency of several previous research results regarding the positive effect of physical activity on increasing student self-esteem $[9,26,27]$. In Indonesia, research on self-esteem, especially those associated with physical activity, sports, and physical education, is rarely documented. The author argues that additional research is needed because even though learning in schools has been made in such a way, self-esteem is not sufficiently honed at the previous education level and is not able to help students participate in active and participatory learning [28].

The physical activity used by the author is the traditional game of the Sundanese tribe in Indonesia in physical education learning. Traditional games are games or sports activities that are regulated by game rules which are inherited from their ancestors by the community (children) to get the joy [29]. Traditional games can stimulate various aspects of child development, such as motor aspects [30], cooperation, sportsmanship [31], and health [32].

Considering the problems above, the purpose of this study was to determine the results of the intervention of Sundanese ethnic traditional games in Physical Education learning on the self-esteem of elementary school children.

\section{Methods}

This research is pre-post quasi-experimental research. This study involved two groups, the experimental group and the control group. The experimental group was given a traditional Sundanese Indonesian game program in physical education learning. The control group was given physical education learning without Indonesian Sundanese traditional games.

\section{Participants}

Participants in this study were all students of grade 6 at an elementary school in Bandung, Indonesia, totaling 11 classes comprising 374 students. The reason the authors chose grade 6 as the study population is because at the age of 6 elementary schools in the development of psychology is the final stage of childhood and at this stage, the child learns to acquire skills and knowledge about what to do and how to do it. If the acquisition is successful, then there will be a sense of ability and passion. But if you meet failure, let alone known by adults, you will feel inferior [33].

\section{Sampling procedures}

From a total population of 11 classes with a total of 374 students at the elementary school, the authors used cluster random sampling to determine the sample group and the control group. In the second stage, using the Random Assignment technique to redraw the two classes that have been drawn in the first stage using cluster random sampling so that the experimental class and control class are obtained. From the random results of the second stage, one class 6 , totaling 30 students, was selected as the experimental group and one class 6 as the control group, which amounted to 30 students, so that the total sample in this study was 60 students. The author collaborates with the school in asking permission to do so in the selected class as the sample. The physical education teachers have a role in conducting research.

\section{Materials and apparatus}

The instrument used in this study was the Self-esteem rating scale (SERS) questionnaire adopted and modified from Nugent and Thomas [34], which was used to measure self-esteem from self-evaluation components including self-worth, social competence, problem-solving abilities, 
intellectual ability, self-competence, and worth relative to other people. The reliability of this instrument is alpha 0.97 .

In conducting the pre and post-test the writer used a self-esteem questionnaire, the equipment used in collecting the data, the writer needed several questionnaire sheets to be distributed to students. As for giving treatment for 12 weeks, the author uses traditional Sundanese games in physical education learning. The equipment needed in giving treatment, the author requires a few balls for boyboyan games, stilts for stilts, sticks/cones for biking games, sticks, and small bamboo for gatrik games.

\section{Procedures}

This research is an experimental study for 12 weeks, and one treatment week for the experimental and control groups. The experimental and control groups were both given treatment, what distinguished them was that the experimental group was given treatment in the form of Sundanese traditional games from Indonesia in physical education learning, while the control group was only given physical learning treatment without any traditional Sundanese games.

This research was conducted from January to March 2020. The research was conducted every Saturday because the Physical Education learning at Ujung Berung Elementary School for grade 6 was on Saturday.

There are only a few traditional Sundanese games that are considered to have relevance in physical education learning. The essence of traditional games from traditional activities can be seen from the number of movements involved. There are traditional Sundanese games that contain a lot of movement, and there are also traditional sports that contain very minimal physical movement but are rich in artistic values such as singing and sacred prayers. On this basis, the authors chose the types of traditional Sundanese games that contain a lot of physical activity including Boyboyan, Galah asin, Engklek, Bebentengan, Hahayaman, Ucing kup/patung, Gatrik, Kelom batok, Egrang, Sorodot gaplok, Luncat tali.

The games are given for 30 minutes to 45 minutes at the beginning of Physical Education lessons before continuing with the core learning of Physical Education. In the field, the writer was assisted by a physical education teacher at Ujung Berung Elementary School, making it easier to carry out research.

\section{Research ethics}

Before the study began, the research protocol had been approved by the Ujung Berung Primary School. The researcher gave a letter of request to conduct research to headmaster of the Ujung Berung elementary school. All selected research samples were asked for their consent to be included in the research. The research sample is free to refuse participation in the study without any consequence. All costs related to the research covered by the researcher and the sample researches were awarded the prize in accordance with the ability of researchers.

\section{Design or data analysis}

This research design is a quasi-experiment design with a nonequivalent control group design. In this study, there was one group that would be given intervention, namely traditional Sundanese games, and another group as a control group who were not given intervention with traditional Sundanese games. The data analysis technique used paired t-test and independent t-test.

\section{Results}

The results of a paired t-test analysis for groups that use traditional Sundanese ethnic games in physical education learning and those that do not use traditional Sundanese ethnic games for physical education learning can be seen in Table 1.

From table 1 it can be seen in the experimental group that after the implementation of the treatment using traditional Sundanese ethnic games in Physical Education learning, the average self-esteem of the experimental group increased by 4.200 . The results of the paired t-test obtained $\mathrm{p}<0.05$ and $\mathrm{t}$ count $>\mathrm{t}$ table, so it can be stated that there is a significant difference in the experimental group's self-esteem before and after the implementation of traditional Sundanese ethnic game treatment in Physical Education learning. Whereas in the control group that did not use traditional Sundanese ethnic games, physical education learning had increased by 0.357 . The results of the paired t-test in the control group obtained $p$ value $>0.05$ and $t$ count < t table, so it can be stated that there is no significant difference in the control group's self-esteem before and after the implementation of the treatment that does not use traditional Sundanese ethnic games in education learning physical.

Table 1. Data Paired t-test Self Esteem Experiment and Control Groups

\begin{tabular}{cccccc}
\hline Test & Group & Mean & t account & t table & p-value \\
\hline Pre-test & Experiment & 40,133 & 2,830 & 2,143 & 0,013 \\
Post-test & Experiment & 44,333 & & & 0,730 \\
Pre-test & Control & 40,643 & 0,352 & 2,160 & \\
Post-test & Control & 41,000 & & & \\
\hline
\end{tabular}


Table 2. Independent T-Test Results on Self-Esteem Differences between Experiment Group and Control Group

\begin{tabular}{|c|c|c|c|c|}
\hline Variable & Mean & t account & t table & p-value \\
\hline Self-esteem Experiment Group & 4,200 & \multirow{2}{*}{2,108} & \multirow{2}{*}{2,052} & \multirow{2}{*}{0,044} \\
\hline Self-esteem Control Group & 0,357 & & & \\
\hline
\end{tabular}

The explanation of the results of the Independent Sample t-test data for the experimental group and control group can be seen in Table 2 .

Table 2 shows that after the implementation of the treatment using Sundanese ethnic traditional games in Physical Education learning, the average value of self-esteem in the experimental group was 4.200, while in the control group it was only 0.357 . This shows that the increase in the experimental group after the implementation of the treatment using Sundanese ethnic traditional games in physical education learning was greater than 3,843 compared to the control group. In the independent $\mathrm{t}$-test results obtained a significance value of $\mathrm{p}$ $<0.05(0.044<0.05)$, which means that there is a significant difference in self-esteem between the experimental group and the control group.

\section{Discussion}

Increased self-esteem will have an impact on reducing the level of mental illness in childhood. Meanwhile, through physical activity, the traditional games of Indonesian Sundanese ethnicity will increase students' self-esteem and indirectly have an impact on good and positive mental health outcomes.

Our findings reveal that participation in Sundanese ethnic traditional games in the form of physical activity and sports positively affects self-esteem. Consistent with previous research [35,36], these findings add to the literature on sports participation that helps build the student self-esteem.

Our results supported some research about physical activity through traditional games can improve self-concept in physical and self-esteem [27,37,38]. Be more specific about the possible influence of physical activity on self-esteem, and it turns out that a good physical concept will be followed by an increase in self-esteem in several studies [39]. Traditional play seems to be an effective intervention that can improve current therapy, can be seen from using a robust design, as well as analysis is needed to determine the type of traditional game intervention that can produce better self-esteem.

This research was conducted within the scope of physical education learning in schools. School in this context includes organizational, instructional, and social aspects that affect the student development [40,41]. The main factor in increasing student development is school involvement, school involvement is an action that directs students to active activities in school which results in a positive influence on self-esteem.[42,43]. This opinion can be seen from two viewpoints of social calculation [44] and a symbolic interactionist point of view [4]. The emotional influence of the school can affect self-esteem as a feedback from the experiences between individual students and become a reference for the feeling of being valued and accepted by students at school [45]. And increase the sense of belonging to the school [46], which in turn can increase their self-esteem. Whereas symbolic interactionist, self-concept is the result of social behavior that provides a relationship of self-esteem on school involvement [4]. Self-esteem which is an important part of self is created as a result of judgments and judgments that are reflected in other people which are very important in social interactions. Therefore, it makes sense that school involvement (for example, activities through assignments given by the school and how students are disciplined and obey the rules set in school and participation in extracurricular activities of Sundanese ethnic traditional games) contribute to positive feedback and evaluation.

Although it has been proven that traditional game interventions in physical education learning can increase self-esteem in this study, there are several drawbacks that the authors feel can influence the results of this study, although it is not clear whether this influence is large or small. First, the sample that is too minimal uses only 60 samples which are divided into control and experimental groups. Second, the traditional Sundanese ethnic game intervention is placed in Physical Education learning, it becomes a bit biased whether the increased self-esteem is the influence of traditional games or physical education learning, although this concern is limited by the presence of a control group. Third, it is still unclear that the increase in self-esteem actually occurs directly due to Sundanese ethnic traditional games or Sundanese ethnic traditional games increasing the competence of sports / traditional games so that the increased competence can increase self-esteem. This author's concern is based on several studies based on hierarchically structured self-concept theory [47], and according to the EXSEM 'model of exercise and self-esteem'[48], that the increase in self-esteem is not directly influenced by the involvement of students in the physical activity of traditional Indonesian Sundanese games, but physical activity becomes a link so that students feel increased competence due to physical activity of the traditional games of the Indonesian Sundanese tribe [49]. EXSEM is a continuous process between the physical abilities that students get through physical activity, and continues to increase the ability in sports which in turn can increase self-esteem. The 
relationship of physical activity to self-esteem which is mediated by an increase in physical ability and sports competence has been developed in previous studies that it is felt by children, especially elementary school students in this study [50]. Seeing this phenomenon, schools should strive to position physical abilities and sports competence as the main factors in increasing student self-esteem, and can use Physical Education classes to improve physical abilities and sports. [51,52].

\section{Conclusion}

Based on the results of the research and discussion that have been described and explained earlier, it can be concluded that through traditional Sundanese ethnic games, elementary school students' self-esteem can increase. It is also hoped that school involvement (participation and implementation of traditional Sundanese ethnic games in schools) can contribute to positive feedback and evaluation. As for the shortcomings in this study which have been discussed in the discussion points, the authors hope there will be further research so that traditional Sundanese ethnic games can continue to be developed in the learning process of children.

\section{Acknowledgement}

The authors thank Dini Dwijayanti as a physical education teacher who has provided facilities in data collection, and does not forget all reviewers who have provided input to make this article better.

\section{REFERENCES}

[1] Rosenberg M. Conceiving the Self. New York, NY: Basic Books; 1979.

[2] Harter S. Historical roots of contemporary issues involving self-concept. In: Bracken BA, ed. The Handbook of Self Concept. Wiley, editor. New York, NY; 1996. 1-37 p.

[3] Fox K. The effects of exercise on self-perceptions and self-esteem. Physical A. New York, NY: Routledge; 2000. 88-117 p.

[4] Harter S. The construction of the self: A developmental perspective. New York, NY: Guilford Press; 1999.

[5] Mann M, Hosman CMH, Schaalma HP, De Vries NK. Self-esteem in a broad-spectrum approach for mental health promotion. Health Educ Res. 2004;19(4):357-72.

[6] Moksnes UK, Espnes GA. Self-esteem and life satisfaction in adolescents-gender and age as potential moderators. Qual Life Res. 2013;22(10):2921-8.

[7] Sowislo JF, Orth U. Does low self-esteem predict depression and anxiety? A meta-analysis of longitudinal studies. Psychol Bull. 2013;139(1):213-40.

[8] Aryana M. Relationship Between Self-Esteem and Academic Achievement Amongst Pre-University Students. J Appl Sci. 2010;10(20):2474-7.

[9] Ahn S, Fedewa AL. A Meta-analysis of the Relationship Between Children's Physical Activity and Mental Health. 2011;1-13.

[10] Faulkner G, Duncan M. Physical activity and mental health: A focus on depression. Routledge. Abingdon: Routledge; 2018.

[11] Poitras VJ, Chaput JP, Gray CE, Carson V, Gruber R, Olds $\mathrm{T}$, et al. Systematic review of the relationships between sleep duration and health indicators in school-aged children and youth. Appl Physiol Nutr Metab. 2016;41(6):S266-82.

[12] Warburton DER, Nicol CW, Bredin SSD. Choroba wieńcowa wśród kobiet - Czy istnieje problem płci? Fam Med Prim Care Rev. 2006;8(3):1110-5.

[13] Yudha BAR. Hubungan Anxiety Dengan Keterampilan Pitcher Softball (Suatu Studi Kejuaraan Softball Gorgeous Cup 2012). J Educ FKIP UNMA. 2017;3(1):7-12.

[14] Biddle SJH, Asare M. Published as: Biddle, S. J. H., \& Asare, M. (2011). Physical activity and mental health in children and adolescents: A review of reviews. 2011;88695 .

[15] Pilar Matud M, Bethencourt JM, Ibáñez I. Relevance of gender roles in life satisfaction in adult people. Pers Individ Dif [Internet]. 2014;70:206-11. Available from: http://dx.doi.org/10.1016/j.paid.2014.06.046

[16] American Association of Suicidology. Youth suicidal behavior- Fact sheet: Prevention of youth suicides and suicidal behavior. 2010 .

[17] Sharaf AY, Thompson EA, Walsh E. Support on Suicide Risk Behaviors among At-Risk Adolescents METHODS : FINDINGS : 2009;22(3):160-8.

[18] Fisher S, Zapolski TCB, Sheehan C, Barnes-najor J Addictive Behaviors Pathway of protection : Ethnic identity, self-esteem, and substance use among multiracial youth $i \vec{\gamma}$. Addict Behav [Internet]. 2017;72:27-32. Available from: http://dx.doi.org/10.1016/j.addbeh.2017.03.003

[19] Farrington DP, Gaffney H, Ttofi MM. Systematic reviews of explanatory risk factors for violence, offending, and delinquency. Aggress Violent Behav. 2017;33:24-36.

[20] Adams SK, Kuhn J, Rhodes J. Self-Esteem Changes in the Middle School Years: A Study of Ethnic and Gender Groups. RMLE Online. 2006;29(6):1-9.

[21] Stice E. Risk and maintenance factors for eating pathology: A meta-analytic review. Psychol Bull. 2002;128(5):825-48.

[22] Resnick MD, Bearman PS, Blum RW, Bauman KE, Harris KM, Jones J, et al. From Harm Longitudinal Study. Jama. 1997;278(10):823-32.

[23] Zhang L. Moderating effects of gender and age on the relationship between self-esteem and life satisfaction in mainland Chinese. 2002;37(2):83-91. 
[24] Zhao J, Wang Y, Kong F. Exploring the mediation effect of social support and self-esteem on the relationship between humor style and life satisfaction in Chinese college students. Pers Individ Dif [Internet]. 2014;64:126-30. Available from: http://dx.doi.org/10.1016/j.paid.2014.02.026

[25] Lu M, Yang G, Skora E, Wang G. Research in Autism Spectrum Disorders Self-esteem , social support, and life satisfaction in Chinese parents of children with autism spectrum disorder. Res Autism Spectr Disord [Internet]. 2015;17:70-7. Available from: http://dx.doi.org/10.1016/j. rasd.2015.05.003

[26] Ekeland E, Heian F, Hagen KB. Can exercise improve self esteem in children and young people? A systematic review of randomised controlled trials. $\mathrm{Br} \mathrm{J}$ Sports Med. 2005;39(11):792-8.

[27] Liu M, Wu L, Ming Q. How does physical activity intervention improve self-esteem and self-concept in children and adolescents? Evidence from a meta-analysis. PLoS One. 2015;10(8):1-17.

[28] Bahri A. UPAYA SEKOLAH DALAM PEMBENTUKAN SELF ESTEEM. J Media Komun Pendikan Teknol dan Kejuru. 2018;5(1):7-15.

[29] Achroni K. Mengoptimalkan Tumbuh Kembang Anak Melalui Permainan Tradisional. Yogyakarta: Javalitera; 2012.

[30] Kusumawati O. Pengaruh permainan tradisional terhadap peningkatan kemampuan gerak dasar siswa sekolah dasar kelas bawah. J Pendidik dan Pembelajaran Dasar. 2017;4:124-42.

[31] Yudiwinata HP, Handoyo P. Permainan Tradisional dalam Budaya dan Perkembangan Anak. Paradigma. 2014;02:1-5.

[32] Guo Y, Shi H, Yu D, Qiu P. Health benefits of traditional Chinese sports and physical activity for older adults: A systematic review of evidence. J Sport Heal Sci [Internet]. 2016; (July):1-11. Available from: http://dx.doi.org/10.10 16/j.jshs.2016.07.002

[33] Hurlock EB. Developmental Psychology: A Lifespan Approach. Boston: McGraw Hill; 1990.

[34] Nugent WR, Thomas JW. Validation of a Clinical Measure of Self-Esteem. Res Soc Work Pract. 1993;3(2):191-207.

[35] Chen WI, Chen CY, Lin YH, Chen TT. Sport participation and self-esteem as mediated by perceived peer acceptance and sport self-concept in Taiwanese college students. Soc Behav Pers. 2012;40(4):699-704.

[36] Daniels E, Leaper C. A longitudinal investigation of sport participation, peer acceptance, and self-esteem among adolescent girls and boys. Sex Roles. 2006;55(11-12):87580.

[37] Babic MJ, Morgan PJ, Plotnikoff RC, Lonsdale C, White RL, Lubans DR. Physical Activity and Physical Self-Concept in Youth: Systematic Review and Meta-Analysis. Sport Med. 2014;44(11):1589-601.

[38] Spruit A, Assink M, van Vugt E, van der Put C, Stams GJ.
The effects of physical activity interventions on psychosocial outcomes in adolescents: A meta-analytic review. Clin Psychol Rev [Internet]. 2016;45:56-71. Available from: http://dx.doi.org/10.1016/j.cpr.2016.03.00 6

[39] Lubans D, Richards J, Hillman C, Faulkner G, Beauchamp M. Physical Activity for Cognitive and Mental Health in Youth : A Systematic Review of Mechanisms. 2016;138(3).

[40] Eccles JS, Midgley C, Wigfield A, Buchanan CM, Reuman D, Flanagan C, et al. Conclusioneccles, Jacque, Paper 1.Pdf. 1993.

[41] Morin AJS, Maïano C, Marsh HW, Nagengast B, Janosz M. School life and adolescents' self-esteem trajectories. Child Dev. 2013;84(6):1967-88.

[42] Danneel S, Colpin H, Goossens L, Engels M, Leeuwen K V, Noortgate WVD, et al. Emotional school engagement and global self-esteem in adolescents: Genetic susceptibility to peer acceptance and rejection. Merrill-Palmer Quarterly-Journal Dev Psychol. 2019;65(2):158-182.

[43] Mihalec-Adkins BP, Cooley ME. Examining individual-level academic risk and protective factors for foster youth: School engagement, behaviors, self-esteem, and social skills. Child Fam Soc Work. 2020;25(2):256-66.

[44] Leary MR, Baumeister RF. The nature and function of self-esteem: Sociometer theory. Adv Exp Soc Psychol. 2000;32:1-62.

[45] Fredricks JA, Blumenfeld PC, Paris AH. School engagement: Potential of the concept, state of the evidence. Rev Educ Res. 2004;74(1):59-109.

[46] Baumeister RF, Leary MR. The Need to Belong: Desire for Interpersonal Attachments as a Fundamental Human Motivation. Interpers Dev. 2018;117(3):57-89.

[47] Shavelson RJ, Hubner JJ, Stanton GC. Self-Concept: Validation of Construct Interpretations. Rev Educ Res Summer. 1976;43(3):407-41.

[48] Sonstroem, R.J \& Morgan W. Exercise and Self-Esteem: Rationale and Model. Med Sci Sports Exerc. 1989;21(3):329-37.

[49] Estevan I, Barnett LM. Considerations Related to the Definition, Measurement and Analysis of Perceived Motor Competence. Sport Med [Internet]. 2018; Available from: https://doi.org/10.1007/s40279-018-0940-2

[50] Slutzky CB, Simpkins SD. The link between children's sport participation and self-esteem: Exploring the mediating role of sport self-concept. Psychol Sport Exerc [Internet]. 2009; 10(3): 381-9. Available from: http://dx.doi.org/10.1 016/j.psychsport.2008.09.006

[51] Harter S. The Construction of the Self. Developmental and Sociocultural Foundations. 2nd ed. New York, NY: The Guilford PresS; 2012.

[52] Whitehead J., Corbin CB. Self-esteem in children and youth: The role of sport and physical education. In K. R. F. Champaign: Human Kinetics.; 1997. 175-203 p. 